\title{
Zastosowanie technologii laserowych w branży motoryzacyjnej na przykładzie firmy Volkswagen Poznań
}

\author{
Laser technologies in automotive industry \\ on the example of Volkswagen company
}

\section{Streszczenie}

W przemyśle motoryzacyjnym coraz częściej konwencjonalne metody spajania, takie jak zgrzewanie oporowe czy spawanie MIG/MAG, zastępowane są technologiami laserowymi. Artykuł prezentuje przykłady zastosowania nowoczesnych technologii laserowych do produkcji nowego Volkswagena Craftera we Wrześni. Omówione w nim zostały budowa i podstawy działania laserów włóknowych, rozróżnienie laserów emitujących wiązkę pojedynczą i potrójną, a także charakterystyka procesów spawania i lutospawania laserowego. Przedstawione zostały również rezultaty wykorzystania opisanych technologii do spajania blach karoseryjnych.

Słowa kluczowe: laser; spawanie laserowe; branża motoryzacyjna; wiązka lasera

\begin{abstract}
Nowadays more and more conventional jointing methods used in an automotive industry like a resistance welding or MIG/MAG welding are replaced by laser techniques. This article presents some examples of modern laser technology used during production of the new model of Volkswagen's Crafter in the factory located in Września. In the above article construction and theoretical background of an action of fiber lasers as well as characteristics of laser welding and braze welding processes were discussed. Also the results of mentioned techniques used during the bonding of body sheets were presented.
\end{abstract}

Keywords: laser; laser welding; automotive industry; laser beam

\section{Wstęp}

Technologie laserowe znajdują zastosowane niemalże w każdej dziedzinie życia- od innowacyjnych, zaawansowanych technologicznie urządzeń wykorzystywanych w przemyśle zbrojeniowym i medycynie po małe urządzenia codziennego użytku, takie jak na przykład wskaźniki. Skoncentrowana wiązka laserowa jest źródłem ciepła o najwyższej gęstości mocy dostępnej w przemyśle. W branży motoryzacyjnej spajanie laserowe to najistotniejsza z technologii wykorzystujących laser jako źródło ciepła. Świadczy o tym jego coraz powszechniejsze zastosowanie oraz intensywny rozwój na przestrzeni ostatnich lat. Niewielkie jeziorko spawalnicze oraz mała ilość ciepła wprowadzana do materiału znacząco ogranicza wielkość odkształceń cieplnych w porównaniu do konwencjonalnych metod spawania. Obróbka po procesie jest zbędna, a złącze charakteryzuje się wysoką odpornością zarówno statyczną, jak i dynamiczną. Możliwość zastosowania dużych prędkości spawania oraz wysoka powtarzalność procesu znacznie obniżają koszty zastosowania technologii laserowej przy zachowaniu wysokiej jakości połączeń.

\section{Rodzaje laserów stosowanych w spawalni Crafter}

\section{Lasery włóknowe}

Lasery włóknowe stanowią odpowiedź na problemy wynikające z kształtu aktywnego medium stosowanego $w$ tradycyjnych laserach na ciele stałym. Zastosowanie długiego i cienkiego czynnika aktywnego w laserze prowadzi do znaczącej poprawy zarówno właściwości termicznych, jak i optycznych lasera. Ze względu na wysoką wartość stosunku powierzchni do objętości aktywnego medium, rozpraszanie ciepła i rozkład obciążeń termicznych na całej długości włókna nie wpływa znacząco na jakość wiązki. Jest ona jednak uzależniona od właściwości fizycznych włókna [1].

Włókno w laserze składa się z rdzenia i pancerza. Rysunek 1 przedstawia schemat budowy włókna aktywnego lasera. Rdzeń jest najczęściej wzbogacony o metale ziem rzadkich. Zarówno światło z diod, jak i promieniowanie lasera przechodzą przez włókno. Na końcach włókna znajdują się lustra lub bramki Bragga, które wypuszczają z włókna promieniowanie o określonej długości wiązki.

Mgr inż. Agata Pawłowska - Volkswagen Poznań, Politechnika Poznańska.

Autor korespondencyjny/Corresponding author: agata.pawlowska1@gmail.com 


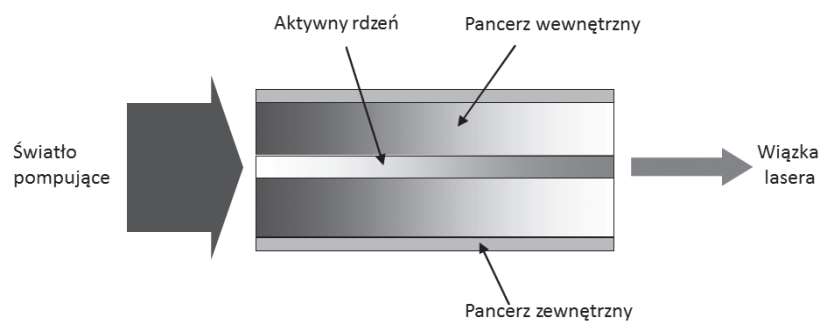

Rys. 1. Budowa włókna aktywnego lasera [2]

Fig. 1. The structure of the active fiber [2]

Lasery włóknowe mogą osiągać moc nawet 100 kW. Emitują wiązkę o długości 1,07 $\mu \mathrm{m}$. Wydajność elektryczna mieści się w przedziale od 20 do $30 \%$ [3].

Rysunek 2 przedstawia zależność jakości emitowanej wiązki od mocy generowanej przez laser dla przedstawionych powyżej urządzeń. BPP (ang. Beam Parameter Product) to współczynnik określający zbieżność wiązki, czyli jej jakość. Dla idealnej wiązki wskaźnik ten powinien wynosić 0 , co jest jednoznaczne z tym, że wiązka ma stałą średnicę na całej długości. Im wyższa wartość współczynnika tym gorsza jakość wiązki. W praktyce współczynnik BPP wynosi dla laserów o wysokiej mocy mieści się w granicach od 0,3 do $25 \mathrm{~mm} \cdot \mathrm{mrad}$.

Przy mocach niższych niż 10 W wskaźnik BPP laserów Nd:YAG wzbudzanych lampą i diodami jest niemal równy. Stanowi on jedną dziesiątą wartości tego wskaźnika dla wiązki lasera gazowego $\mathrm{CO}_{2}$ oraz lasera diodowego. Świadczy to o gorszej jakości wiązek emitowanych przez laser diodowy $\mathrm{i} \mathrm{CO}_{2}$ przy niskich mocach $\mathrm{w}$ porównaniu do laserów Nd:YAG. Jednak w przypadku wyższych mocy, stosowanych w spawalnictwie jakość wiązki lasera $\mathrm{CO}_{2}$ zachowuje stały poziom, a pogorszeniu ulega jakość pozostałych wiązek. Najwyższą jakością charakteryzują się wiązki emitowane przez laser dyskowy i włóknowy.

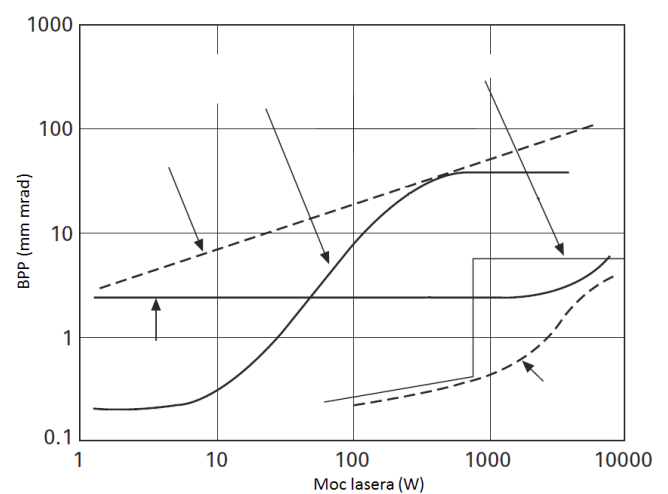

Rys. 2. Jakość wiązki emitowanej przez różne źródła laserowe w odniesieniu do mocy tego lasera [4]

Fig. 2. The quality of laser beam emitted by different laser's sources in relation to the power of laser [4]

\section{Lasery włóknowe jednowiązkowe i trójwiązkowe}

Przy budowie samochodu użytkowego Crafter we Wrześni wykorzystywane są dwa rodzaje laserów włóknowych: jedno- i trójwiązkowe dostarczane przez firmę IPG Photonics. Lasery te niezależnie od typu charakteryzują się budową modułową. Moc poszczególnych modułów może wynosić od 500 do 1500 W, a ich ilość jest uzależniona od wymaganej mocy urządzenia. Maksymalna moc dostępnego na rynku lasera wynosi 100 kW. Sprawność tych urządzeń waha się w granicy $50 \%$. Wiązki emitowane przez poszczególne moduły są doprowadzane za pomocą światłowodów do sprzęgacza.Tam następuje ich połączenie i dalsza emisja za pomocą głównego światłowodu do głowicy spajającej. Długość fali powstałej wiązki wynosi $1070 \mathrm{~nm}$. Rysunek 3 przedstawia poglądowy schemat budowy tego typu lasera.

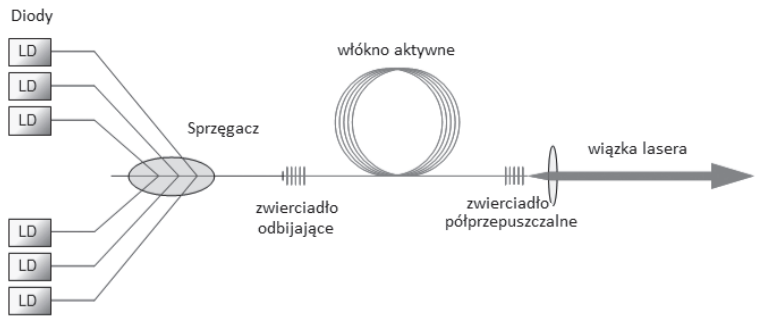

Rys. 3. Budowa włókna aktywnego lasera [2]

Fig. 3. The structure of the active fiber [2]

Laser trójwiązkowy stanowi modyfikację lasera podstawowego, czyli jednowiązkowego. W porównaniu do tradycyjnych metod spajania takich jak spawanie czy zgrzewanie, proces laserowy charakteryzuje się bardzo wysokimi szybkościami nagrzewania i chłodzenia. Efektem tego jest ryzyko zachodzenia bezdyfuzyjnych przemian fazowych. Szczególnie w przypadku stali austenitycznych złącza mogą charakteryzować się wysoką twardością i kruchością. Zastosowanie w tym przypadku dodatkowej wiązki znacząco poprawia jakość złącza, przez zredukowanie procentowej zawartości martenzytu w strukturze. Spawanie podwójną wiązką jest także wykorzystywane do spawania stali galwanizowanych. Pierwsza wiązka ma za zadanie odparować powłokę cynkową, przygotowując w ten sposób "ścieżkę" dla spoiny. Druga wiązka jest odpowiedzialna za utworzenie złącza [5]. Usunięcie warstwy cynku pomaga zredukować niezgodności złącza takie jak rozpryski i porowatość. Jako metody usunięcia tej warstwy literatura podaje na przykład obróbkę mechaniczną lub spawanie wiązką lasera w dwóch przejściach lub zastosowanie technologii hybrydowych (metoda TIG wraz z laserem) [6]. Budowa lasera trójwiązkowego różni się od lasera jednowiązkowego ilością modułów oraz budową światłowodu doprowadzającego wiązkę lasera do spajanego elementu. Oprócz modułów, które składają się na moc głównej wiązki, w urządzeniu znajdują się dwa dodatkowe moduły. Każdy z nich generuje promieniowanie dla poszczególnej wiązki pomocniczej. Wewnątrz światłowodu znajdują się trzy włókna, jedno dla wiązki głównej oraz dwa dla pomocniczych.

Rysunek 4 przedstawia schemat umieszczenia wiązek wewnątrz światłowodu oraz uzyskaną tą metodą spoinę. Trzy zestawy próbek z ocynkowanych blach karoseryjnych o grubości 0,8 oraz 1,2 mm zostały zespawane. Złącza zostały wykonane wiązką „falującą”. Optyka głowicy została wprowadzona w ruch posuwisty oraz wahadłowy. Przykład A pokazuje spoinę wykonaną w sposób tradycyjny, jedną wiązką. Ta spoina charakteryzuje się największą niejednorodnością i nierównością lica. Widoczne są również pory na powierzchni. Dodatkowo na blasze widoczny jest rozprysk ciekłego metalu. Spoina B została wykonana metodą trójwiązkową. Wiązki pomocnicze wyprzedzają główną wiązkę spawającą. Ich zadaniem jest przygotowanie materiału do spawania. Wstępne podgrzanie oraz oczyszczenie blachy z warstwy cynku sprawia, że lico spoiny jest gładsze i nie obserwuje się rozprysku. Na początku i na końcu widoczne są kratery. Próbka została również wykonana metodą trójwiązkową. W tym przypadku wiązki pomocnicze „podążają" za wiązką główną. W ten sposób obniża się szybkość chłodzenia, a powierzchnia lica spoiny jest bardziej wyrównana, w porównaniu do spawania laserowego pojedynczą wiązką. Zastosowanie dodatkowych wiązek wykazuje jednak największą skuteczność przy spawaniu spoin prostych, takich jak pokazuje przykład D. Tylko w tym przypadku wiązki pomocnicze zawsze znajdują się w tym samym położeniu względem kierunku spawania. Niezależnie od tego, czy umieszczone są przed, czy za główną wiązką. 


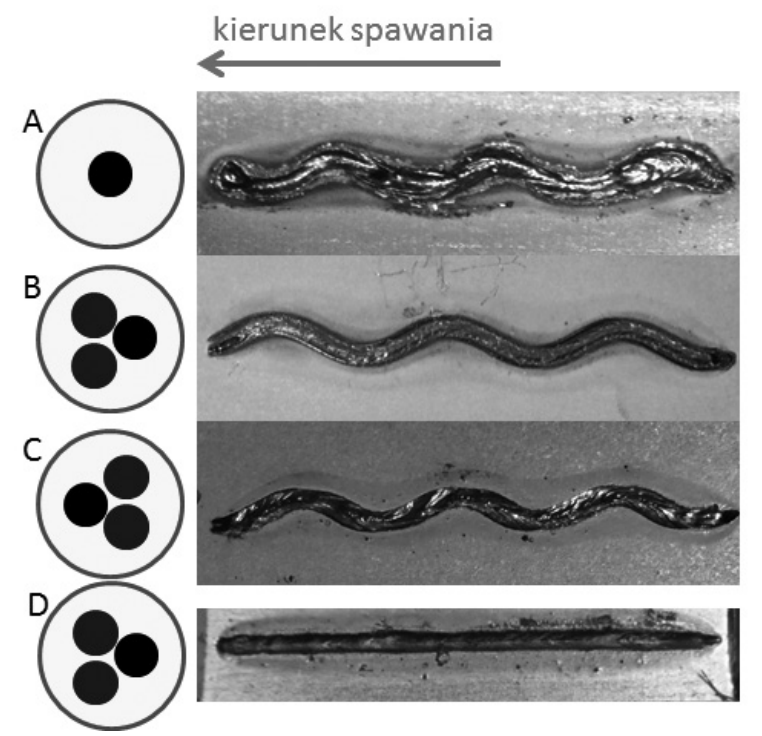

Rys. 4. Schemat umieszczenia wiązek $w$ światłowodzie lasera oraz lica uzyskanych spoin

Fig. 4. Scheme of the placement of beams in fibre-optic cable and examples of obtained faces of welds

\section{Zastosowanie innowacyjnych technologii laserowych przy budowie samochodu Crafter}

Technologie laserowe są coraz szerzej wykorzystywane w branży motoryzacyjnej. W fabryce samochodów użytkowych Crafter w dziale budowy karoserii użytkowanych jest 10 źródeł laserowych. Cztery urządzenia wykorzystują pojedynczą wiązkę spawającą, a pozostałe trzy wiązki. Lasery są wykorzystywane do spawania i lutowania w kabinach laserowych. Rysunek 5 przedstawia kabinę laserową znajdującą się w fabryce samochodu Crafter we Wrześni.
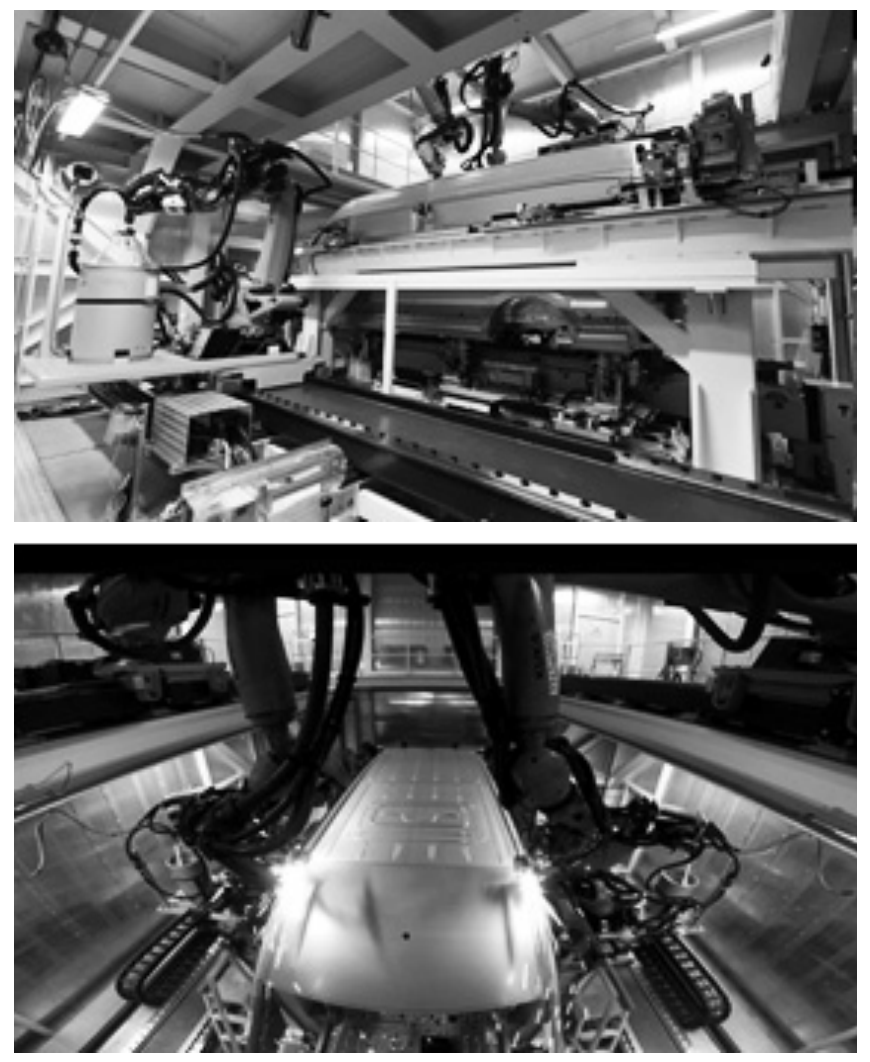

Rys. 5. Widok kabiny laserowego systemu spawalniczego stosowanego w spawaniu konstrukcji pojazdu

Fig. 5. The view on laser welding system used in welding of the car's construction
Za pomocą spawania laserowego łączony jest dach z całą karoserią. Wykorzystywana jest do tego celu głowica spawająca firmy Permanova. Proces ten opiera się na spawaniu pojedynczą wiązką. Ściany samochodu Crafter są lutowane potrójną wiązką z zastosowaniem głowicy spawającej z taktylnym układem śledzenia złącza. Procesy te znajdują zastosowanie w branży motoryzacyjnej już od kilku lat. Szerzej tematykę lutowania laserowego potrójną wiązką opisał E. Majeran na przykładzie samochodu Caddy [7].

\section{Połączenie zgrzewania i spawania laserowego}

Nowością $\mathrm{w}$ polskim przemyśle jest proces $\mathrm{z}$ pogranicza zgrzewania i spawania, wykorzystujący laser. Wykorzystywane jest do tego celu urządzenie LSS1 - Laser Seam Stepper. Elementy spajane są do siebie dociskane, z kontrolowaną siłą mogącą osiągać wartość do $3 \mathrm{kN}$. Podobnie jak ma to miejsce w przypadku zgrzewania oporowego punktowego - najszerzej stosowanej technologii spajania w branży motoryzacyjnej. Następnie odbywa się spawanie z wykorzystaniem pojedynczej wiązki laserowej. Proces odbywa się bez obecności gazów osłonowych. Jego największą zaletą jest fakt, że urządzenie jest laserem klasy 1, bezpieczne $w$ racjonalnie przewidywalnych warunkach pracy, także w przypadku patrzenia w wiązkę przez przyrządy optyczne. Urządzenia te nie muszą być użytkowane w kabinach laserowych, w przeciwieństwie do laserów klasy 4, które mogą stanowić zagrożenie już przy odbiciach rozpraszających. Mogą spowodować obrażenia skóry oraz zagrożenia pożarem [9]. Rysunek 6 przedstawia schemat stanowiska do przygotowywania próbek za pomocą urządzenia LSS1. Składa się ono z głowicy urządzenia LSS1 zamontowanej na robocie przemysłowym KUKA oraz systemu mocowania próbek.

Urządzenie pozwala na wykonywanie połączeń o przebiegu "sinusoidalnym", przedstawionych na rysunku 4. W zależności od zastosowanych parametrów możliwe jest uzyskanie różnych efektów. Oprócz standardowych parametrów takich jak moc spawania i prędkość spawania istnieje możliwość regulacji częstotliwości pracy ruchu wahadłowego. W efekcie regulujemy częstotliwość pojawiania się "fal”.

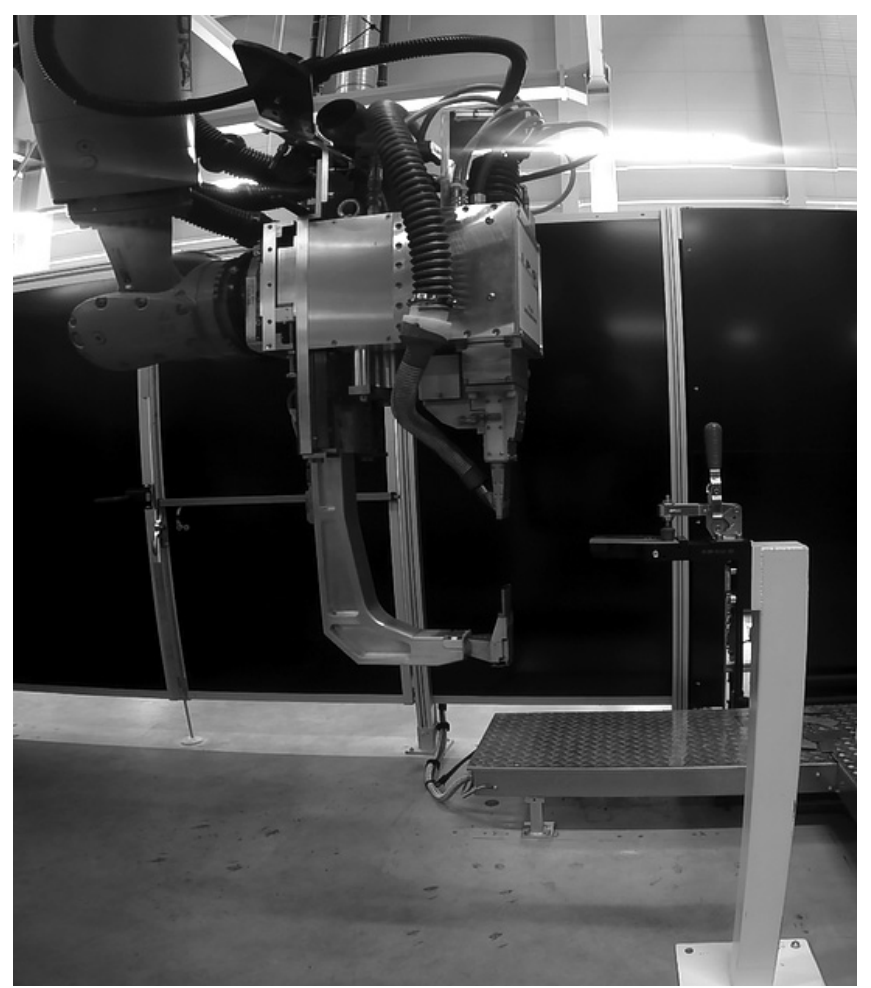

Rys. 6. Schemat stanowiska do przygotowywania próbek za pomocą urządzenia LSS1

Fig. 6. The test stand for laser welding with LSS1 


\section{Próby spawania urządzeniem LSS1}

Próby spawania urządzeniem LSS1 polegały na przygotowaniu partii próbek z blach karoseryjnych o grubości 0,9 i $0,75 \mathrm{~mm}$. Obie blachy zostały poddane procesowi galwanizacji. Grubsza blacha została ocynkowana ogniowo, a cieńsza elektrolitycznie. Rysunek 7 przedstawia przykładową partię próbek spawania laserowego. Każda próbka została pospawana innymi parametrami.

Próbki zostały poddane ocenie zgodnie z normą DIN EN ISO 13919-1[10]. Rysunek 8 przedstawia przykładowe: lico, grań spoiny oraz zgład metalograficzny. Wklęsłość lica spoiny wynosi 0,68 mm, a głębokość wtopienia 0,20 mm. Obydwa parametry mieszczą się w granicach określonych przez normę.

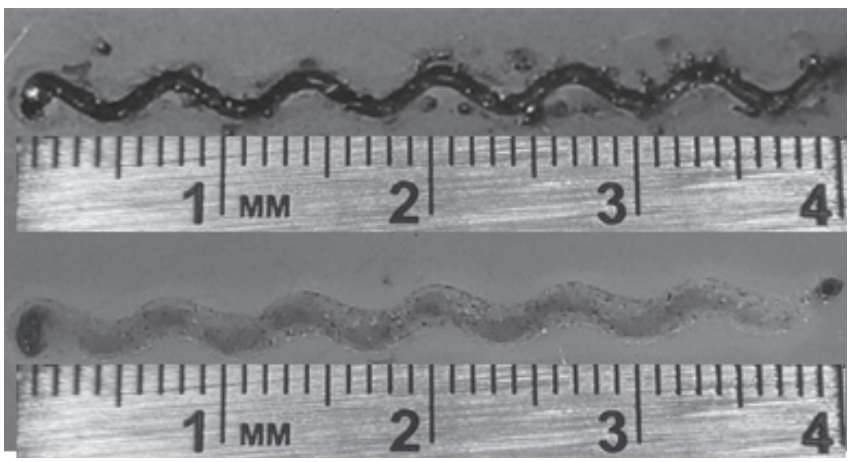

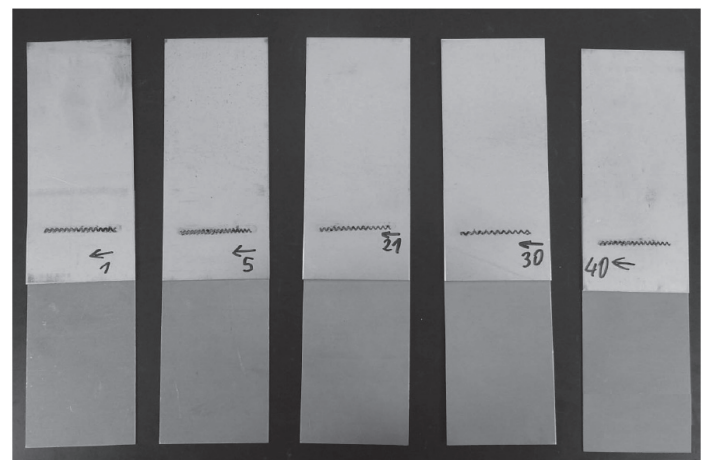

Rys. 7. Próbki spawania wykonane urządzeniem LSS1 Fig. 7. Examples of welds prepared with LSS1

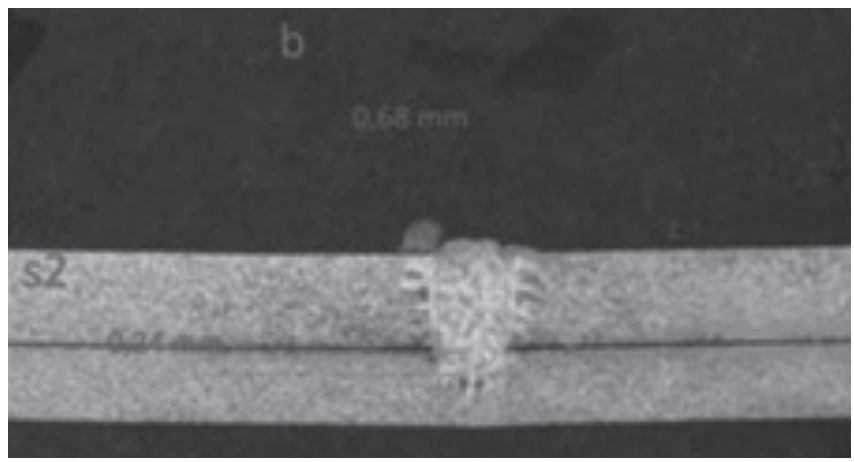

Rys. 8. Lico, grań oraz zgład metalograficzny spoiny wykonanej urządzeniem LSS1

Fig. 8. Face, root and polished section of the weld prepared with LSS1

\section{Wnioski}

Spawanie urządzeniem LSS1, pojedynczą wiązką umożliwia spajanie blach karoseryjnych cynkowanych ogniowo oraz elektrolitycznie.

Mniejsza ilość ciepła wprowadzanego do materiału w porównaniu do konwencjonalnych metod spajania gwarantuje ograniczenie odkształceń cieplnych.

Możliwość dwustronnego dociskania elementów podczas spawania urządzeniem LSS1 redukuje konieczność zastosowania skomplikowanych i kosztownych systemów mocowania detali.

Spawanie urządzeniem LSS1 wymaga mniejszej powierzchni niż ma to miejsce w przypadku zgrzewania oporowego. Pozwala to na redukcję wymiarową, a tym samym obniżenie masy samochodu.

Zastosowanie w spawalnictwie laserów klasy 1 wpływa na zmniejszenie kosztów inwestycyjnych związanych z przygotowaniem stanowiska roboczego. Dodatkowo poprawia bezpieczeństwo pracowników obsługujących stację i pracujących w pobliżu.

Uzyskane w wyniku spawania laserowego połączenia mogą skutecznie zastąpić zgrzeiny punktowe. Czas ich wykonania jest krótszy, a ograniczenia wynikające z charakterystyki procesu mniej dokuczliwe. Nie występuje tu tak zwany efekt bocznikowania prądu.

\section{Literatura}

[1] Majumdar J. D., Manna I.: Laser material processing, International Materials Reviews, 56, s. 46-47, 2011.

[2] Limpert J. , Schreiber T., Tünnermann A.: Fiber based high power laser systems, s. 1-6, www.rp-photonics.com/highpowerfiberlasers.html (odwiedzona 30.08.2017)

[3] Katayama S.: Introduction: fundamentals of laser welding, Handbook of laser welding technologies, Joining and Welding Research, Institute Osaka University, 11-1 Mihohaoka, Ibaraki, Osaka, Japonia, pp. 3-7, 2013.

[4] Dobrzański L.A., Dobrzańska-Danikiewicz A.D.: Obróbka powierzchni materiałów inżynierskich, Open Access Library, Volume 5, s. 183-193, 2011.

[5] Różański M., Morawiec M., Grajcar A., Stano S.: Modified twin-spot laser weIding of complex phase steel, Arch. Metall. Mater, Vol. 61, pp. 1999, 2016.

[6] K-M. Hong, Y.C. Shin: Prospects of laser welding technology in the automotive industry. A review, Journal of Materials Processing Technologies, 245, pp. 52, 2017.
[7] Majeran E.: Lutowanie laserowe w przemyśle motoryzacyjnym metodą Trifocal na przykładzie tylnej klapy Volkswagena Caddy, Przegląd Spawalnictwa, Vol. 88, Nr 9, s. 14-17, 2016.

[8] Krastel K.: New production tool for energy-efficient joining technology in automotive manufacturing, Sheet Metal Welding Conference XVI, October 22-24, 2014.

[9] Norma PN-EN 60825-1 Bezpieczeństwo urządzeń laserowych - Część 1. Klasyfikacja sprzętu i wymagania, 2010.

[10] DIN EN ISO 13919-1 Schweißen - Elektronen- und Laserstrahl-Schweißverbindungen; Leitfaden für Bewertungsgruppen für Unregelmäßigkeiten - Teil 1: Stahl, 2002. 